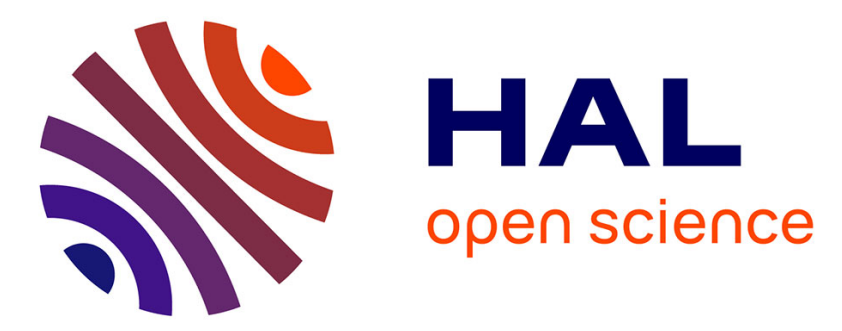

\title{
Long length/small core step-index silicon core fiber fabricated by improved powder-in-tube process
}

Aymeric Pastre, Armand Passelergue, Sébastien Rougier, André Lecomte, Mustafa Ordu, Frédéric Gérôme, Jean-Marc Blondy, Christine Restoin

\section{To cite this version:}

Aymeric Pastre, Armand Passelergue, Sébastien Rougier, André Lecomte, Mustafa Ordu, et al.. Long length/small core step-index silicon core fiber fabricated by improved powder-in-tube process. Conference on Laser and Electro-Optics /Europe (CLEO/Europe-EQEC 2019), OSA, Jun 2019, Munich, Germany. Paper CE-7.6. hal-02331436

\section{HAL Id: hal-02331436 \\ https://hal.science/hal-02331436}

Submitted on 23 Nov 2020

HAL is a multi-disciplinary open access archive for the deposit and dissemination of scientific research documents, whether they are published or not. The documents may come from teaching and research institutions in France or abroad, or from public or private research centers.
L'archive ouverte pluridisciplinaire HAL, est destinée au dépôt et à la diffusion de documents scientifiques de niveau recherche, publiés ou non, émanant des établissements d'enseignement et de recherche français ou étrangers, des laboratoires publics ou privés. 


\title{
Long length/small core step-index silicon core fiber fabricated by improved powder-in-tube process
}

\author{
Aymeric Pastre ${ }^{1}$, Armand Passelergue ${ }^{1}$, Sébastien Rougier ${ }^{1}$, André Lecomte ${ }^{2}$, Mustafa Ordu ${ }^{1}$, Frédéric \\ Gérôme ${ }^{1}$, Jean-Marc Blondy ${ }^{1}$, Christine Restoin ${ }^{1}$ \\ 1. XLIM Research Institute, UMR 7252 CNRS/University of Limoges - 123 avenue Albert THOMAS, 87060 LIMOGES, France \\ 2. IRCER, UMR 7315 CNRS/University of Limoges - Centre Européen de la Céramique, 12 Rue Atlantis, 87068 Limoges Cedex, France
}

The development of silicon-core fibers have drawn strong interest over the last decade. Indeed, silicon is a material offering interesting properties such as mid-wave infrared transparency $(1-7 \mu \mathrm{m})$, high refractive index $(3.48 @ 1.55 \mu \mathrm{m})$ and large third order non linearity $\left(\approx 1.5 \times 10^{-13} \mathrm{~cm}^{2} / \mathrm{W}\right)$. Until now, three fabrication processes have been developed to achieve glass-clad silicon-core fibers: the high-pressure microfluidic chemical deposition method [1], the molten core method from silicon rods [2] and the powder-in-tube method [3]. This last one shows a very high potential to achieve hybrid optical fibers as it allows not only to use a wide range of materials but it is also compatible with the stack-and-draw process ; in this way, many different designs of fibers can be especially drawn. Unfortunately, fibers fabricated by this method are very short, only a few centimetres long because of the mechanical stresses accumulation at the interface between the two materials which have different thermal expansion coefficients $\left(\mathrm{Si}: 3 \times 10^{-6} \mathrm{~K}^{-1} ; \mathrm{SiO}_{2}: 5 \times 10^{-7} \mathrm{~K}^{-1}\right)$, and because of the presence of air between the grains.

For the first time to our knowledge, we present the fabrication of a 50 meters long silicon core fiber with a $5 \mu \mathrm{m}$ core, thanks to a modified powder-in-tube process: a consolidation step has been added during the process in order to control the expansion and the powder density of the silicon. This additional step consists in heating the silicon powder in the preform while controlling the pressure, in order to remove the air trapped between the grains. This consolidation step is carried out in situ, in the drawing tower furnace. The preform, which consists in a silica tube sealed at one end and loaded with silicon powder, is installed in the mandrel. The preform is then heated at a consolidation temperature which is set slightly above the melting temperature of the silicon $\left(\mathrm{T}_{\text {conso }}=1420^{\circ} \mathrm{C}\right)$ under 100 mbar pressure, while moving from the bottom up at a constant speed of $50 \mathrm{~mm} / \mathrm{min}$.

(a)

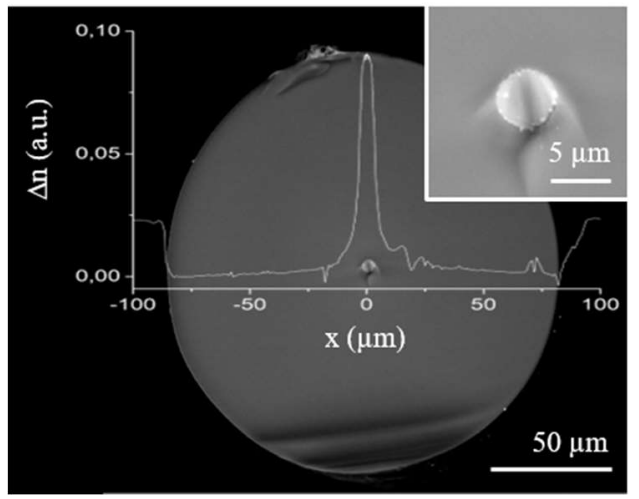

(b)

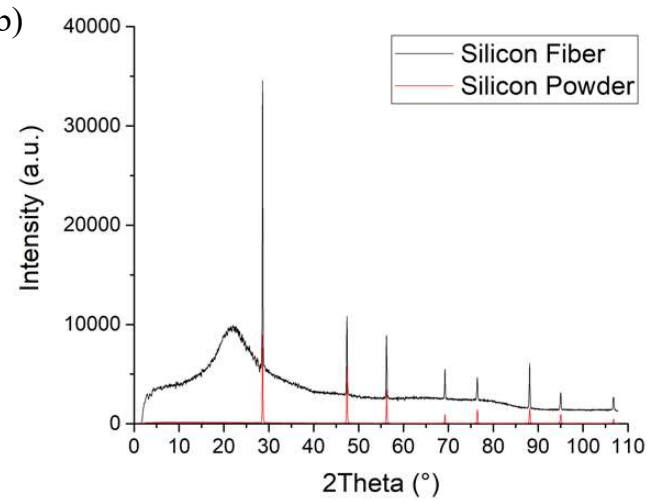

Fig. 1 (a) Scanning electron microscope (SEM) picture of a silicon-core/silica-clad optical fiber drawn using the modified powder-in-tube method (cross-section) with overlayed index profile. Inset: zoom on the core. (b) X-Ray Diffraction (XRD) pattern of silicon powder and of the as-drawn fiber crushed

The SEM picture (Fig. 1(a)) shows the cross-section of the as-drawn fiber. The fiber with a diameter of $170 \mu \mathrm{m}$ exhibits a good core/clad concentricity, a good circularity of the core and a clean core/clad interface as can be seen in the inset. The index profile superimposed to the SEM picture matches perfectly the fiber geometry and confirms the index step between the two materials. Fig.1 (b) presents the XRD patterns of the drawn silicon fiber (black line) compared to the silicon powder (red line). On the black line, the amorphous hump around $20^{\circ}$ corresponds to the silica clad. The results show that there is no $2 \theta$ shift between the two diffractograms. These values also fit those indexed in the JCPDS card 002.0561 corresponding to crystalline silicon. These results confirm that there is no residual stresses in the silicon core. Moreover, the narrowness of the peaks indicates a high degree of crystallinity of the core material composed of large grains.

\section{References}

[1] P. J. A. Sazio, A. Amezcua-Correa, C. E. Finlayson, J. R. Hayes, T. J. Scheidemantel, N. F. Baril, B. R. Jackson, D.-J. Won, F. Zhang, E. R. Margine, V. Gopalan, V. H. Crespi and J. V. Badding, "Microstructured optical fibers as high-pressure microfluidic reactors", Science 311, 1583 (2006)

[2] J. Ballato, T. Hawkins, P. Foy, R. Stolen, B. Kokuoz, M. Ellison, C. McMillen, J. Reppert, A. M. Rao, M. Daw, S. Sharma, R. Shori, O. Stafsudd, R. R. Rice, and D. R. Powers, "Silicon optical fiber" Opt. Express 16, 18675 (2008)

[3] B. Scott, K. Wang, V. Caluori, and G. Pickrell, "Fabrication of silicon optical fiber", Opt. Eng. 48, 100501 (2009) 